\title{
GENERAL (g) ELECTRIC
}

MANFORD ATOMIC PRODUCTB OPERATION - RICHLAND, WASHINGTON

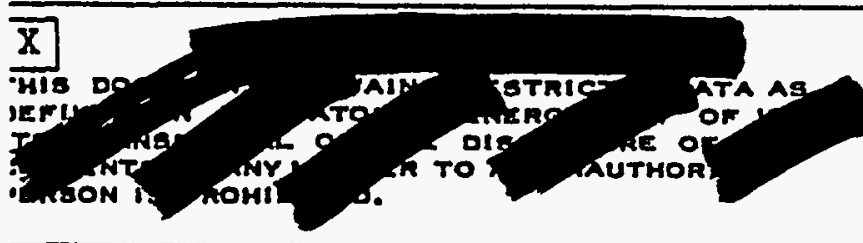

OTHER OFPICIAL CLABEIFIED INFORMATION

"HIE MATERIAL CONTAINB INFORMATION AFFECTING -HE NATIONAL DEFEMEE OF THE UNITED STATES VITHIN THE MEANING OF THE EBPIONAGE LAWS. rITLE IE, U. S.C., BECB. T9S AND 704, THE TRANBAIBEION OR REVELATION OF WHICH IN ANY MANNER PO AN UNAUTHORIZED PERBON IB PROHIRITEO BY AW. TITLE

COPY 1 OF 1 , SERIES MA SERIES AND COPY NO.

$\frac{2}{\operatorname{May} 6,1959}$

INIERTM REPORT ON IABORATORY EXPERIMENISS INVESTIGATIITG CONSEQUENCES OF FAIUURE OF FRONT HYDRAULIC FIITIINGS IN "C" OCD GEOMEYRY

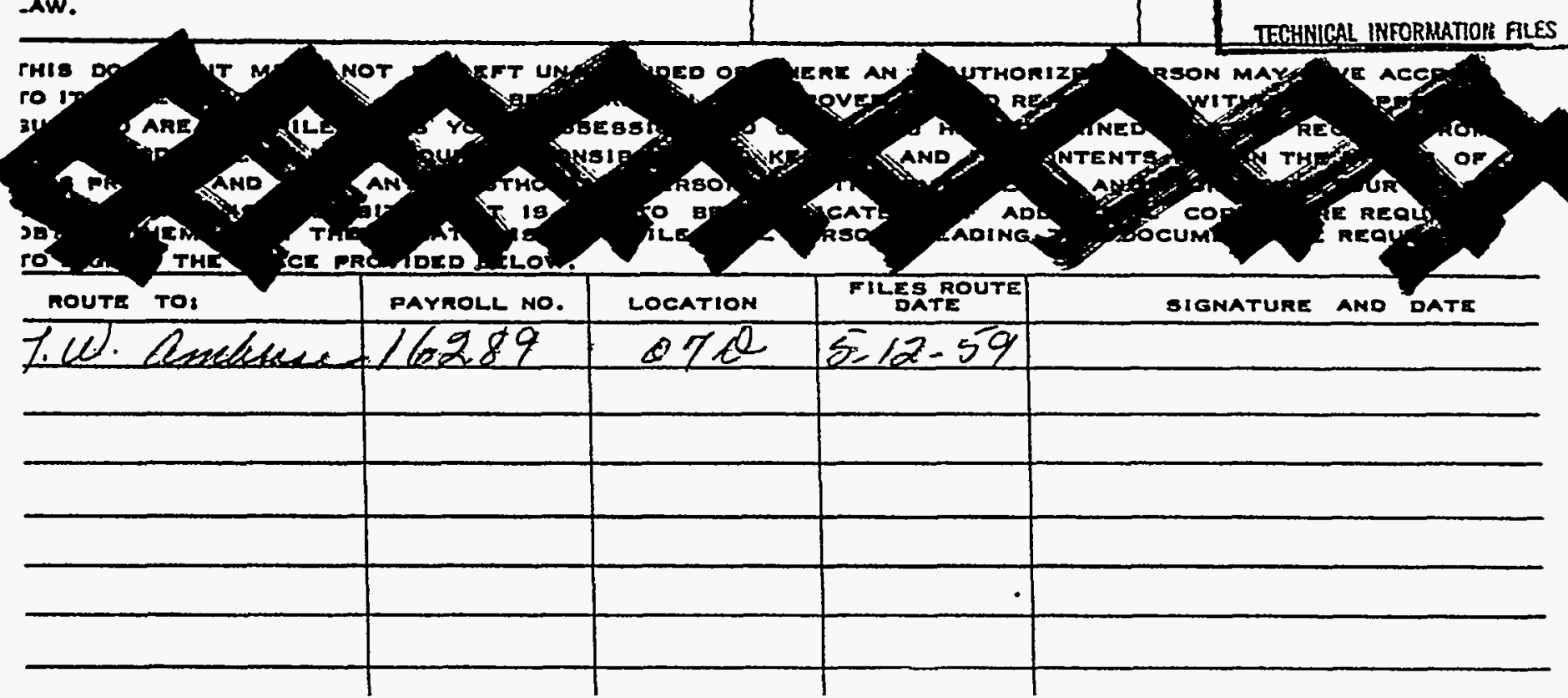

\section{DISCLAIMER}

This report was prepared as an account of work sponsored by an agency of the United States Government. Neither the United States Government nor any agency thereof, nor any of their employees, makes any warranty, express or implied, or assumes any legal liability or responsibility for the accuracy, completeness, or usefulness of any information, apparatus, product, or process disclosed, or represents that its use would not infringe privately owned rights. Reference herein to any specific commercial product, process, or service by trade name, trademark, manufacturer, or otherwise does not necessarily constitute or imply its endorsement, recommendation, or favoring by the United States Government or any agency thereof. The views and opinions of authors expressed herein do not necessarily state or reflect those of the United States Government or any agency thereof.

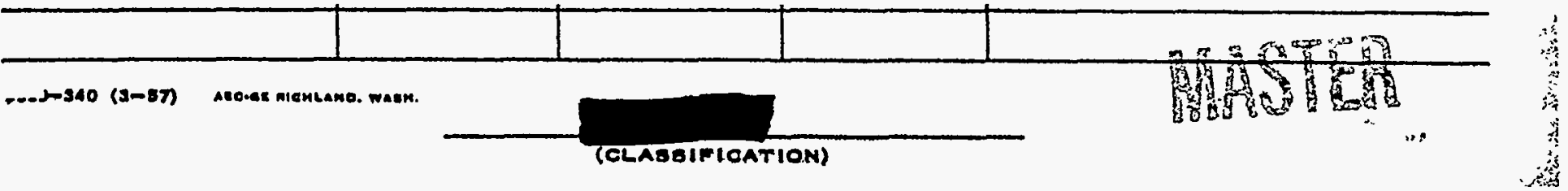




\section{DISCLAIMER}

Portions of this document may be illegible in electronic image products. Images are produced from the best available original document. 


\section{DECLASSFFED}

BW- 60287

Distribution

1. F. W. Albaugh

2. T. W. Ambrose

3. E. R. Astley

4. J. M. Batch

5. J. W. Flonigan

6. D. E. Fitzsimons

7. R. M. Fryar

8. H. Harty

9. G. M. Hesson

10. S. S. Jones.

11. E. B. Ieltz
12. G. I. Iocke

13. I. T. Pedersen

14. R. W. Reid

15. H. G. Spencer

16. P. Thompson

17. R. E. Trumble

18. F. W. Van Wormer

19. B. D. Waters

20. Record Center

21. 300 Files

Nay 6, 1959

This document classifled by

This document consists of

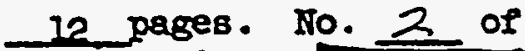

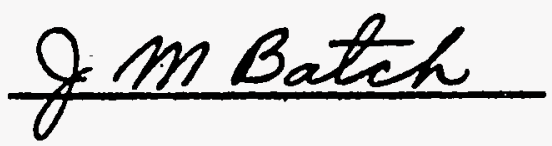

Clasification Cenowind and Chored To

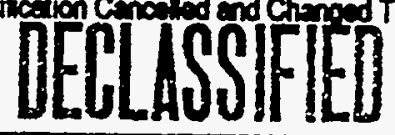

COPY 1 OF 1, SERIES MAA

By Authority or SE Gydesen

$\frac{\text { BLO-CG-4,2-3-94 }}{\text { By } 1 \text { KHAnson, 4-21-94 }}$

Veritiod By of ESarely 4-2i-94.

INTIERTM REPORT ON IABORATORY EXPERTMIINTS

IVVESTICATING COMSEQUENCES OF FATIURE OF

FRONI" HYDRAUTIC FIITIING IN "C" OCD GEOMEIRY

D. B. Fitzsimmons and G. M. Hesson

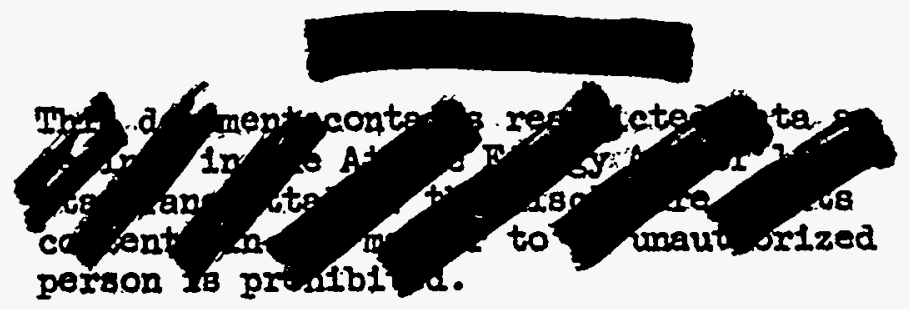

DISTRIBUTION OF THIS DOCUMENT IS UNLIMITED

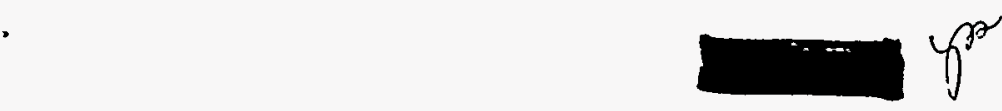




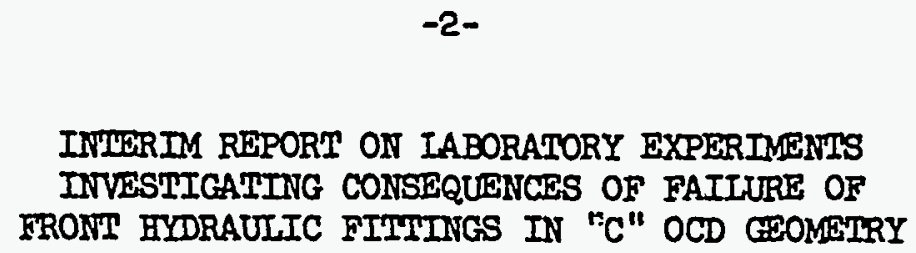

HW- 60287

INTERIM REPORT ON IABORATORY EXPERIMENIS

FRONT HYDRAULIC FITIIIYS IN "C" OCD GEOMEIRY

\section{PURPOSE}

The purpose of this report is to present the results of the most recent transient heat transfer experiments concerning the possibility of damage to a reactor as a result of hIgh slus temperatures should a front hydraulic connector fail to a tube of " $C$ " operational charge-discharge geometry.

\section{INIRODUCTION}

The fallure of a front face hydraullc connector could have serlous consequences to a reactor. While such an incident would Inmediately initlate a scram, the power reduction is dictated by the time required for the insertion of the VSR's and by post-scram delayed f1ssion and f1ssion product decay. Although the post-scram heating is small, the only coolant avallable is that of hot water forced back through the tube by the low pressures of the rear header. This may provide insufficlent cooling, particularly at low rear header pressures.'

Reports of two earlier serles of experfmental tests concerning fallure of a front hydraulic fitting have been 1ssued. $(1,2)$ The f1rst of these presented the results of transient tests designed to determine the minimum rear header pressure necessary to provide an adequate coolant flow. The results were somewhat inconclusive and are belleved to be blghly conservative. The second report presented the results of steady state testg in which reverse direction coolant flow was used under typical reactor rear header pressures and post-scram conditions. While such steady state tests cannot define the consequences of the fallure of a front fitting, information from them 18 of value in explaining the phenomenon of transient tests and in predicting in what areas future transient tests would be most fruitful.

Th1s report presents results of translent tests in which the experimental equipment and procedures' incorporated 1deas gleaned from the two earlier serles. The results should, therefore, be more realistic than those reported prevlously. The planned program was interrupted before completion by an equipment fallure. The information obtalned from the completed tests is slgniflcant, however, and warrants reporting at this time.

\section{SUMMARY}

Nuclear heating of a train of $32 \mathrm{C}$ 出 \& elugs was simulated by electrically heating a rod in a C geometry process tube. Fallure of a front fitting to such a tube was simulated by simultaneously and rapidiy closing a velve in the water supply to the tube and opening a valve in a line which permitted discharge from the inlet of a tube through a front nozzlo to atmosphere. Three to four seconds after the valve operation, a power reduction in accord with a 1500 inhour scram was inftiated. The reverse flow, rear header pressure and elght rod surface temperatures s8 well as other less Important varlables were monftored. A test was continued unt1l conditions of adequate cooling became established. Successive tests were made at successively lowered rear header pressures. All runs reported hereln were at $1000 \mathrm{KW}$ InItIally, and none resulted In excessive rod surface temperatures. The experimental program was terminated by fatilure of the electrical lnaulating varnish on the inside of the process tubes.

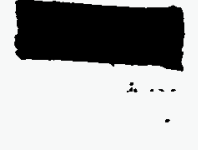




\section{CONCLUSIONS}

$\theta$

In answer to the primary purpose of these tests, the dats show that a process tube of "C" operational charge-discharge geometry operating at $1000 \mathrm{KW}$ can suffer the. loss of coolant from a front fltting fallure if 1 ts rear header pressure were $10 \mathrm{pg} 1 \mathrm{~g}$ or bigher.

Secondary and supporting conclusions are presented below:

0

1. The results of these tests are conservative for a varlety of reasons.

2. The hlghest rod surface temperatures occurred near the outlet of the tube, 1.e., near the inlet of the reverse $110 \%$, and persisted for several minutes after an adequate coolant flow was established. This is ascribed to a stratifled flow regime in this region.

3. Apart from the high temperatures due to strat1fication, establishment of adequate cooling conditions were as estimated fram steady state date in $\mathrm{HW-60164.}$ On thls basis a tube operating Inltially at $1250 \mathrm{KW}$ could suffer loss of coolant from a front fltting fallure if lts rear header pressure were at least 12 to $14 \mathrm{psig}$.

4. These data and conclusions are for " $C$ " reactor operational charge-discharge geometry only. Application to other reactor gecmetries is not valid and 1s probably non-conservative.

0

EXPERIMENTAL APPARATUS AND PROCEDURES

A diagram of the experimental apparatus is presented in Figure 2. The apparatus consists of the test section, the water recirculation system and the electrical generating equipment. The test section is a reasonably accurate prototype of a C reactor process tube from the beglaning of the actlve section to the rear header with the exception that the active section is offset from the dumny section to permit the electrical connections to the heater rod. The test section was lagged to minimize heat losses. At the upstream end the hole and annulus connect to $1^{\text {"plpes which in }}$ turn connect Into a 2 " pipe. The 2 " pipe connects to a $T$, and then through either of two alr-operated valves for operation elther normaliy or with a simulated front Pltting 10ss. The air valves operated in conjunction and in opposite directions, 1.e., when one opens the other closes. For normal operation, the test af ction is connected to the pump discharge and water clrculates through the test section and the water recirculation system. For front fltting fallure simulation, the test section is connected to a C pront nozzle, whose inlet port is connected directly to a $3^{\prime \prime}$ plpe whlch in turn discharges at atmospheric pressure to drain. Thls simulates the case where the front pigtall has stripped loose from the front nozzle.

The heater rod is heated electrlcally by three DC generators whth a nominal output of $1175 \mathrm{KW}$. For these runs the power was controlled wlth a Moseley Model $2 S$ Autograf equipped with curve following accessorles. W1th the curve following accessorles the unit operates as a function generator and was used to control the power in accord with the flrst 150 seconds of a 1500 Inhour scram. For perlods of time greater than 150 seconds power decrease of a scram is very slow and was simulated manually.
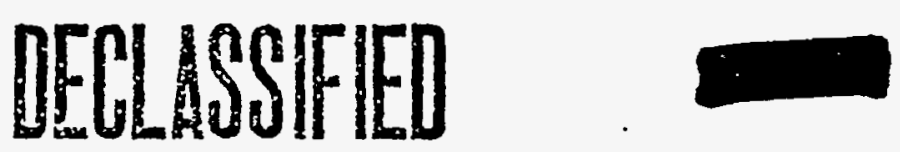
The heater rod was of C I \& E design, $1.464^{\prime \prime}$ OD by $3 / 8^{n}$ ID. The outside diameter was reduced $0.010^{\prime \prime}$ to correct for the $0.005^{\prime \prime}$ thick insulating varnish on the Inside of the process tube. The rod was made of sectlons of brass and copper-nickel alloys welded together. The different electrical resistivitiea of the brass and the varlous copper-nlckel alloys gave a stepwlse form of heat generation whtch approximated a cosine beat generation. Ten thermocouples were imbedded at the top surface of the rod. These gave temperature readings sonewhat higher than, but related to the top of rod surface temperatures. Six hold-down plins were inserted through the top of the process tube at approximately equally spaced intervals along the tube. These were Intended to reduce the upward bowlng the rod undergoes due to vertical temperature gradients during the severe conditions imposed. Flgure 3 shows the heater rod construction, the form of 1 ts heat generation and the thermocouple location.

Loss of a front hydraulic connector was simulated in the following manner: "Normal flow kas established and the tube operated at $1000 \mathrm{KN}$ and $125^{\circ} \mathrm{C}$ outlet water temperature unt1l steady state conditions were reached. Hater was by-passed into the rear header to nalntain 1 ts temperature at 100 to $105^{\circ} \mathrm{C}$. The air-operated valves in the Inlet pipling were then actusted. This shut off the water supply to the tube and opened the inlet port of the front nozzle to atmosphere. Approximately three seconds after the valve actuation a power reduction was started in simulation of a reactor scram. The rear header pressure, reverse flow, several rod surface temperatures as well as other pressures and water temperatures were monltored on bigh speed recording Instruments. Successive runs were at successively lower rear beader pressures. All runs vere continued unt1l attalment of adequate cooling conditions were established by back flow from the rear header.

\section{TEEORY}

The famlliar concepts of a bolling or demand curve and a tube supply curve can be used to describe qualitatively the course of events following the fallure of a front hydraulic fltting. In this case the supply curve is a flat horlzontal line at the approprlate rear header pressure. The bolling or demand curve, whose intersection sith the supply curve determine the operating point, is actualiy a constantly, moving one during the course of the transient. Flgure I graphlcally explains this:

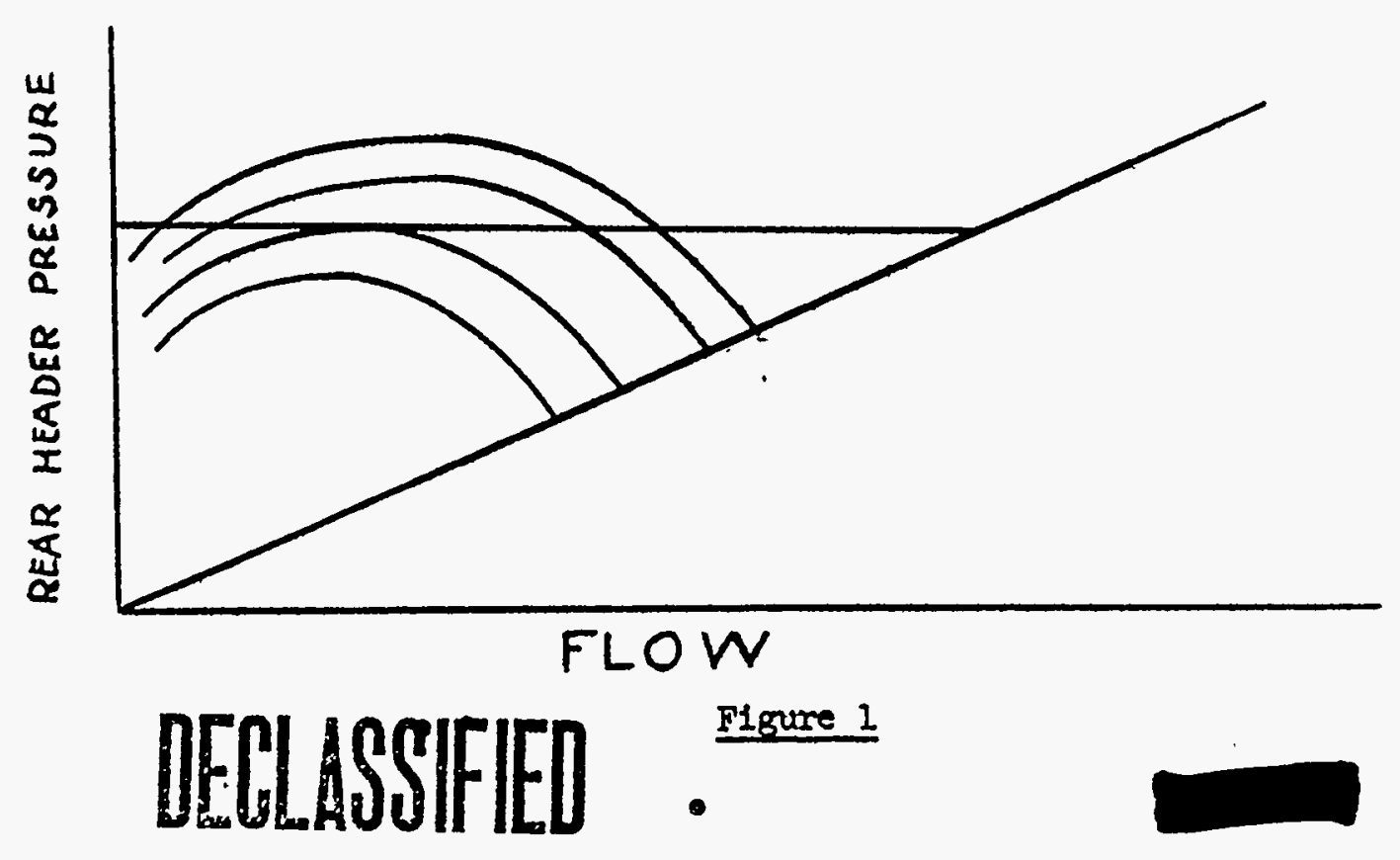


The horlzontal line is the supply curve for a given rear header pressure. The IInes labeled $\theta_{1}, \theta_{2}, \theta_{3}$ and $\theta_{4}$ are the bolling or demand curves for successively later times after the occurrence of the fitting fallure. At time $\theta_{1}$, the operating point is $P_{1}$. At later times, $\theta_{2}$ and ${ }^{-} \theta_{3}$, the operating points are $P_{2}$ and $P_{3}$. At time $\theta_{3}$, the supply curve is tangent to the peak of the bolling curve. At any tine after this, the bolling curve lies below the supply curve and a condition of excess beader pressure exists. When excess header pressure conditions are obtalned, the operating point is $\mathrm{P}_{4}$, the intersection of the supply curve and the non-bolling lsotherm.

These bolling curves cannot be quantitatively determined. Their forn is primarily a function of the heat input co the coolant. The heat input is., in turn, a function of the nuclear heat generation at the time in question and the rate of heat transfer Into the water. The rate of heat transfer to the water is dependent upon the heat transfer coefflclent, and more important, the transient thermal characterlstics of the slugs and the immediate past translent heat accumulation history of the slugs. None of these factors can be determined exactly for a system as complex as a Hanford reactor process tube.

Bolling curves have been determined by steady state experimentation at rear header pressures and water temperaturs and heat generation rates typical to reactor postscram conditions $(3)$. Such curves are equilibrium curves at the conditions which would be reached if the scram power and water temperature decay could be frozen long enough to establish steady state conditions. The moving translent bolling curves would lie below the steady state curves early in the translent while a large part of the generated heat is used in heating the slugs and would lie above the steady state curves later In the translent when the slugs are cooling and releasing heat to the water in addition to that being generated.

Associated with each of the steady state bolling curves are slug surface temperatures. At very early times the equilibrlum temperatures are very high and slug jacket melting would be expected if the equilibriun conditions were reached. At sonewhat later times cooling by bolling would be adequate to prevent slug jacket melting, even at equilibrium.; conditions. St1ll later the condition of excess header pressure with a large water flow is reached, and slug surface temperatures not much higher than the rear header water temperatures would occur. The translent slug surface temperatures would be less then those indicated by the steady state experiments early in the transient while the slugs are heating and would be greater than those later in the transient whlle the slugs are cooling.

An examination of Flgure 1 wlll show that the hlgher the rear header pressure, the sooner adequate cooling conditions will be reached. The problem then is to determine how fast is the slus temperatures rise early in the transient, and, more important, what rear header pressure is necessary to cause the operating polnt to move into adequate cooling reglons before slug surface temperatures are reached which would cause facket melting.

\section{EXPERIMENTAL RESULTS}

Flve runs were completed in this serles before experimentation was balted by an electrical short caused by degradation and fallure of the electrical 1nsulating varnish on the Inside of the process tube. The flrst three runs were at rear header pressures of 15 to $25 \mathrm{psig}$, and attained adequate coollng within 20 to 40 seconds without exceptionaliy high rod surface temperatures. No further results from these runs w1ll be included in thls report. The experimental results for the last two runs is tabulated:In Tables I and II whlch give the behavior of the pertinent varlables with respect to time after the simulated front fltting fallure. 
The next to last mun, Run 53, was made at a rear header pressure whlch varfed between extremes of 6 to $15 \mathrm{ps} 1 \mathrm{~g}$, but which held between 7 to 9 palg during most of the run. During this run the hottest rod surface temperatures were found to occur near the rear beader end of the heater rod on thermocouples which were not being monftored with recording instruments. Temperature data from these thermocouples (Iiumbers 9 and 10) vere obtained by visual observation of steady state indicating instruments, and the - times indicated in Table I are only approximate.

For the last run, Thermocouple 9 and 10 were connected to the recording instruments. The rear header pressure durlng this run varied largely fram 11 to $14 \mathrm{psig}$ with extremes of 9 to $15 \mathrm{psig}$.

The electrical shorts which halted this series occurred at the ribs at the front face end of the test section and near the top of the tube at the rear face end of the test section. This indicates that in spite of the six hold-down pins used in this assembly, the rod tended to bow upwards severely enough to touch the top of the process tube at the rear face end.

\section{DISCUBSION}

$\bullet$

Relterating, the purpose of these tests was to determine the possibility of damages to a reactor due to high slug temperatures arlsing froin the fallure of a front hydraulic connector on a "C" OCD tube. More speciflcally, the tests were intended to define the rear header pressure necessary to cause sufflclent reverse flow through the tube to achleve adequate cooling conditions soon enough to prevent excessive slug temperatures. The data in Tables I and II provlde an answer to this question. The data indicate that a "C" OCD tube operating at $1000 \mathrm{KW}$ can suffer the loss of a front hydraulfc f1tting if the rear header pressure is $10 \mathrm{psig}$ or greater. This answer is not as clear cut as would be desirable because the rear header pressure varied throughout the rmas. However during Run 53, the worst case, the pressure remalned between 7 and $9 \mathrm{psig}$ during most of the mun.

As outlined on page 5, the expected behavlor was an Inftlal large jump in rod surface temperatures between the simulation of the front fltting fallure and the inftiation of: the scram. After the scram the rod surface temperature would be expected to increase at a slow and gradually decreasing rate unt1l adequate cooling conditions rere reached, following which the temperatures would decrease. Colncident with this would be a gradualiy Increas ing reverse flow through the tube. Reverge flow bolling ourves constructed. from steady state.data permitted an estimate of how long after the incident adequate cooling conditions would be reached.

With one important exception, the results of these runs were in accord with the expected behavior. The infitial jump in rod surface temperatire was from $100^{\circ} \mathrm{C}$ to $10^{\circ} \mathrm{C}$ above the InItial temperature. In most cases, the rod surface reached maximum temperatures at times in agieement, acturily somewhat earlier, with those predicted from the steady strate data. In the worst case, tibe maximim temperatiure reached by. these couples wes Iess than $300^{\circ} \mathrm{C}$. Once adequite coolling was reached, the temperature; dropped to within a fow degrees of the coolant temperature.

In one very signiflcant respect, the results of these tests ald dffer from the above; outilned expected behavior. The thermocouples giving the highest temperatures: were the two nearest the rear of the test sect1on, 1.0., nearest the inlet of the reverse flowie Furthermore, these hish temperatures persisted for several minutes after adequate cooline conditions were established as evidenced by the fact that all the other thermocouple locations had cooled and reverge flow rates of 1 to $6 \mathrm{ggm}$ had been reached. The high 


\section{- \\ HW-60287}

temperature polnts were in the reglon of coolest coolant and were outglde the high heat flux reglon and would, therefore, be expected to be the coolest points and to be the I1rst to recover. Some evidence was found in the steady state tests that bigh temperatures might occur near the inlet of the reverse flow. It occurred in only a, few cases, too few to characterlze under what conditions it might be expected.

The reason for this apparently anomalous high temperature location is postulated to arise from the very low llquid veloclties near the coolant inlet. It is belleved that at the low reverse flow rates assoclated with a front fltting failure, the liquid does not 1111 the tube near the inlet end. Th1s leaves part of the rod in a stagnant steam atmosphere above the liquid and cooling is very poor. Farther downstream past the polnt where steam formation starts, the high speciflc volume of the steam results in high velocities and relatively good heat transfer. The low velocity and probable stratifled flow are, therefore, deemed responsible for high temperatures up to the point of steam formation.

The conclusions drawn from these tests are conservative in their application to a reactor for two reasons. First, the test section heater rod yag made to generate all the heat going Into the tube. In a reactor up to 20 per cent (3) of the heat would be generated in the graphite. The experimental heat flux and consequently the rod to coolant temperature difference was, therefore, up to 25 per cent too high. Furthermore, in a reactor a portion of the heat generated in the graphite would be dissipated into the cooler tubes around the affected one.

Secondly, the experimental heater rod bows upward in the process tube. In these tests, six pins were inserted through the top of the tube at three to four foot intervals to restrain the bowing. The pins were not entirely effective. In the reglon of the highest temperature, the pins were found to have indented into the heater rod as much as $1 / 32^{\prime \prime}$. Furthermore, there is undoubtedly some bowing between pins. Such lifting of. the beater in the tube would aggravate any stratiflcation effects.

In conclusion, it must be polnted out again that these results are applicable to a tube of I \& E slugs of C reactor operation charge-discharge gecmetry operating inltially at $1000 \mathrm{KWH}$. Steady state data indicate that such a tube operating at $1250 \mathrm{KH}$ would require a rear header pressure 2 to 4 psig greater than for the $1000 \mathrm{KW}$ case. While the flow mode for the steady state case was different from that of these tranglent testsi, the 2 to $4 \mathrm{psig}$ extrapolation 18 probably reasonable. Extension of these results to other reactor geometries is not warranted.

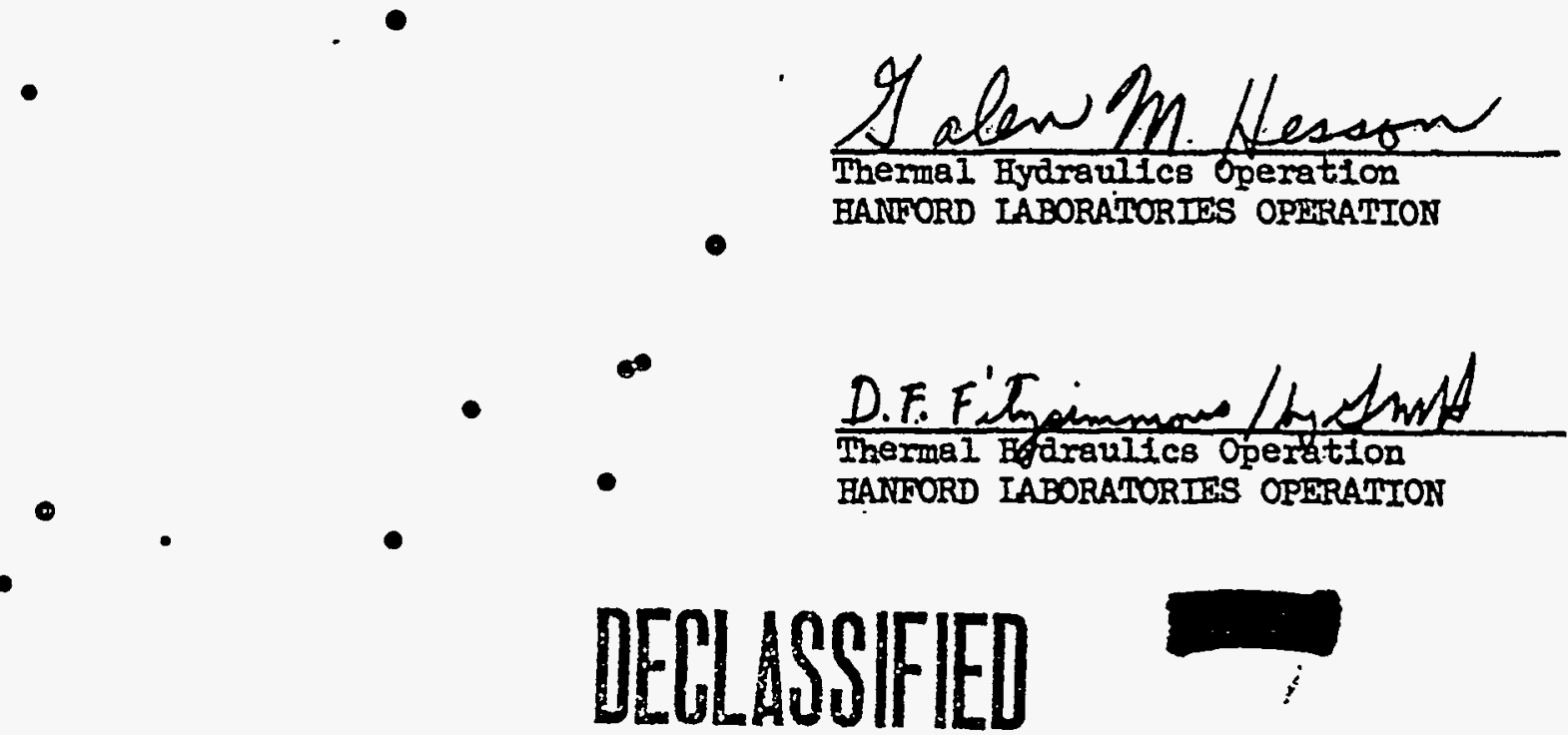




\section{REFERENCES}

6

(1) HW-57740 - Results of Preliminary Tests Simulating Rupture of a Front PIgtall on C Reactor - D. E. Fitzsimmons, G. M. Hesson, October 10, 1958.

0 -

(2) HW-60164 - Results of Reverse Flow Experimental Tests For C Operational Charge-Discharge Tube at Low Tube Powers - D. E. Fitzsimmons, G. M. Hesson, April 30, 1959.

$\odot \odot$

(3) HW-38870 - Heat Generation and Total Heat Output From the P1le After Shutdown - S. S. Jones, November 23, 1954.

$\odot$

8

$\theta$

c

6

0

- 0

c

-

0

0

ㅇ

0

o

0

๑

0

6

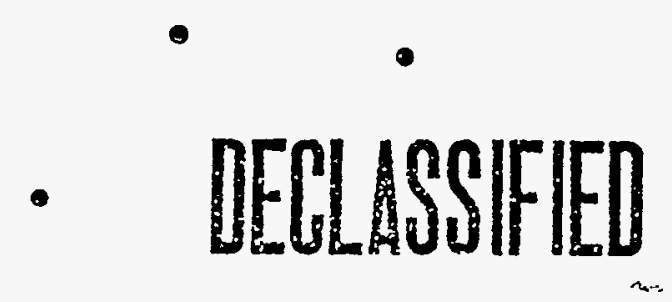


TABRE I

EXPERDAMNIAL RESUTHE FROM RUN 53

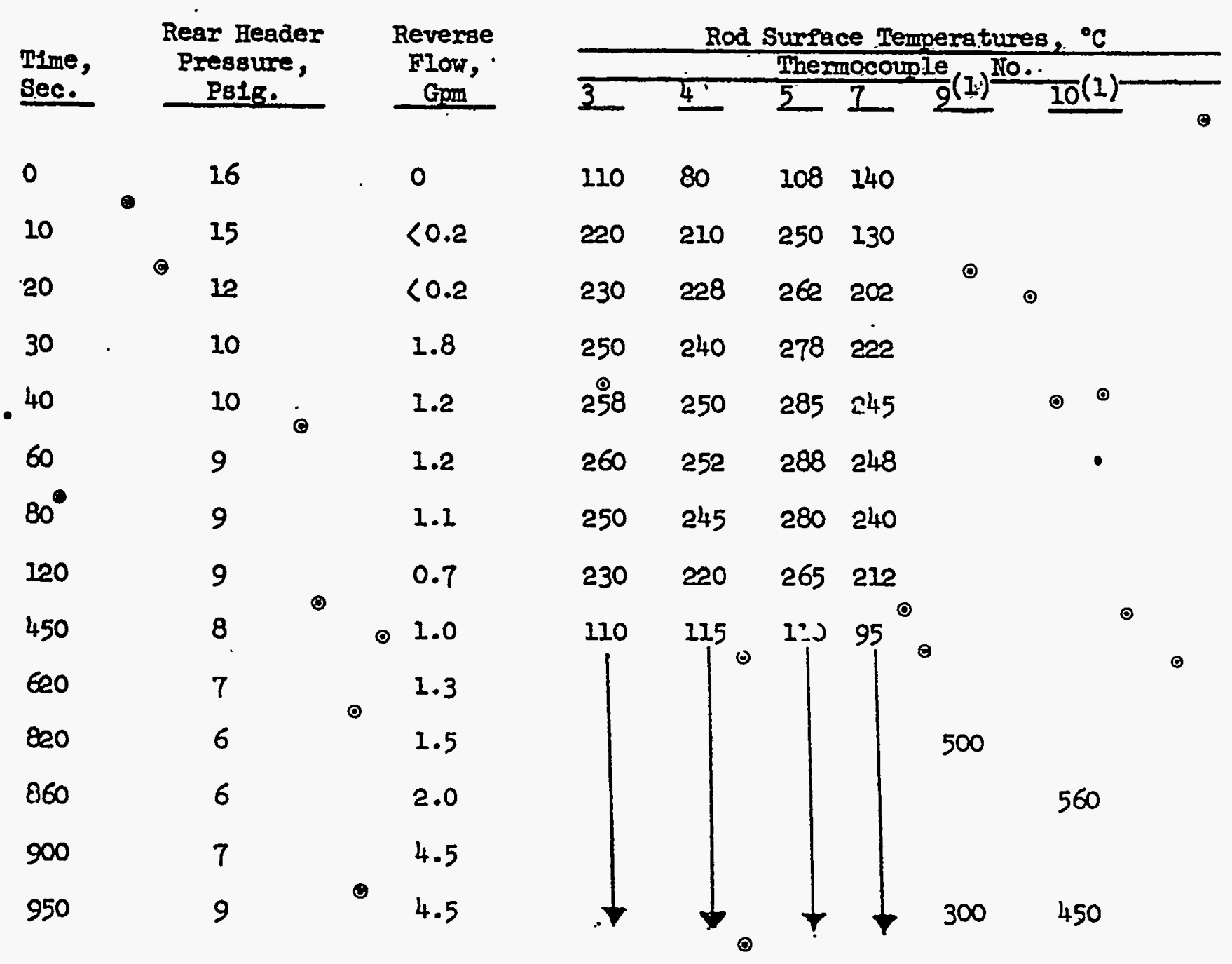

Notes

$\odot$

(1) The rod surface themocouples 9 and: 10 were read rom steady state Indicating instruments during this run. The times are approximate. 
TABLE II

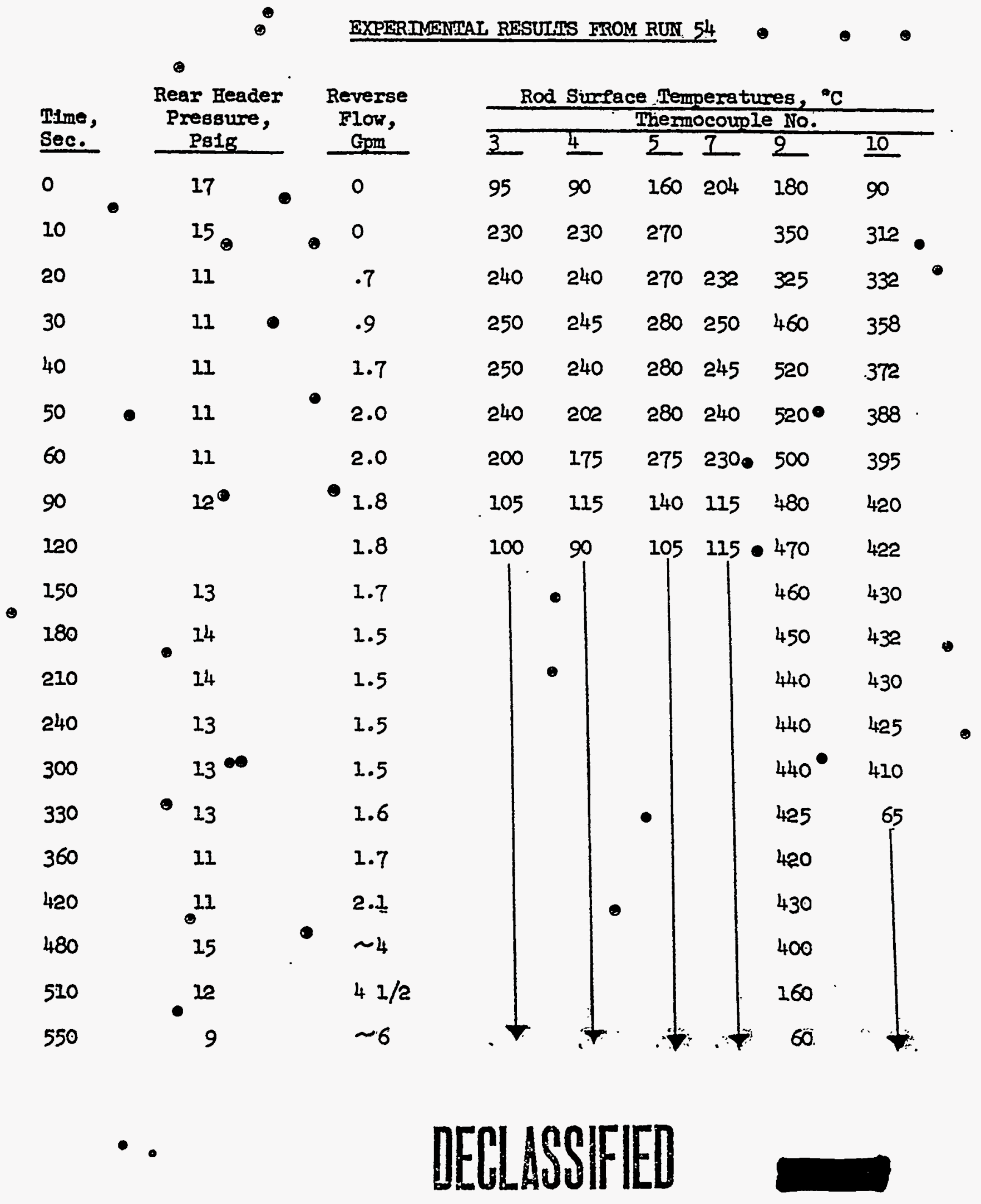



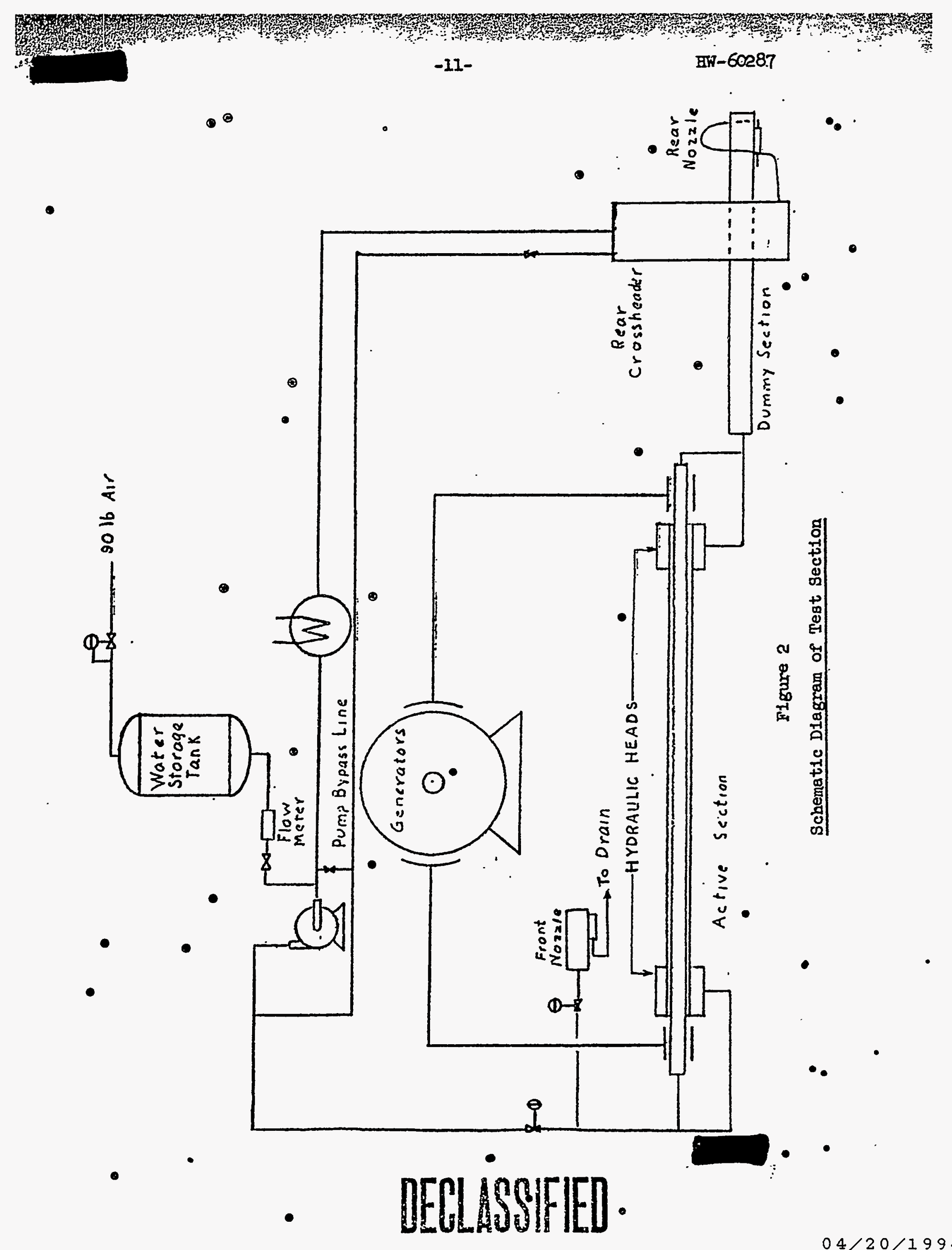


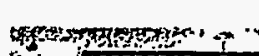

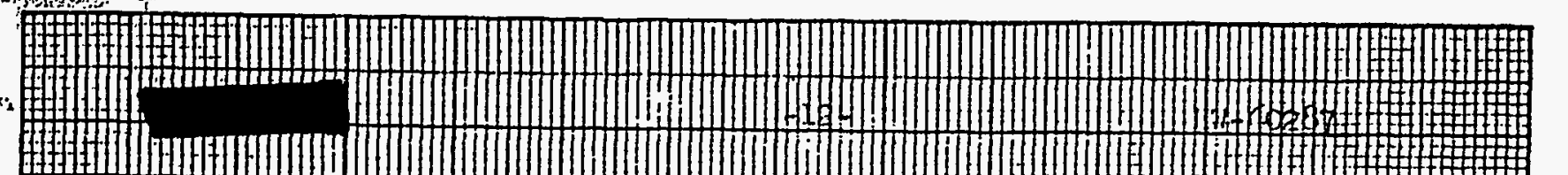

Y ¿ (1)

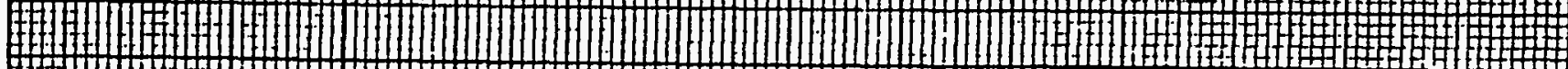

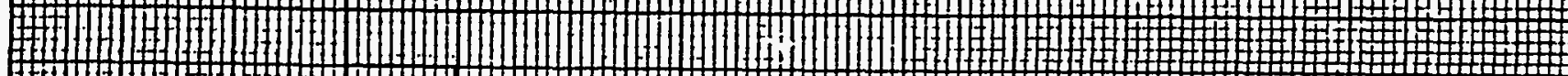

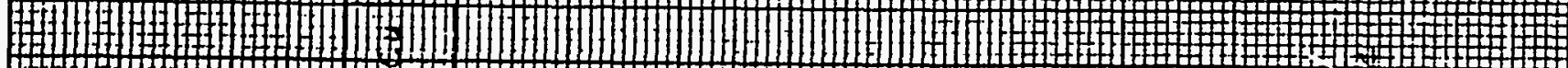

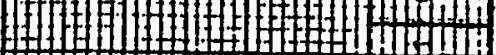

(2)

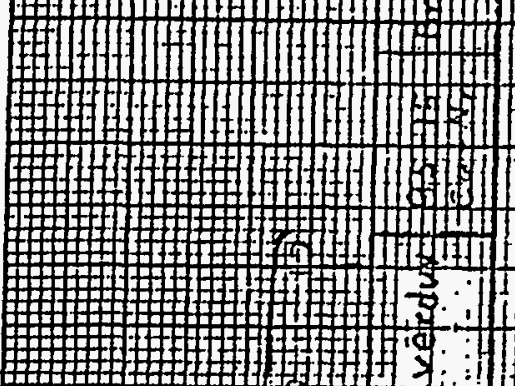

(i)

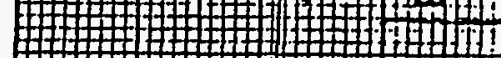

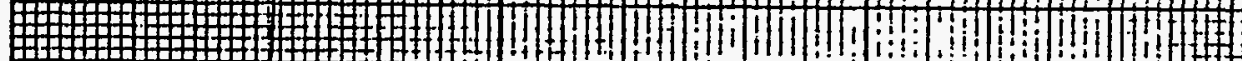

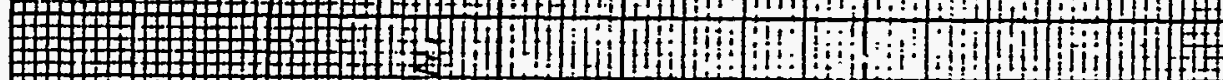

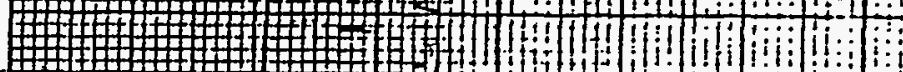

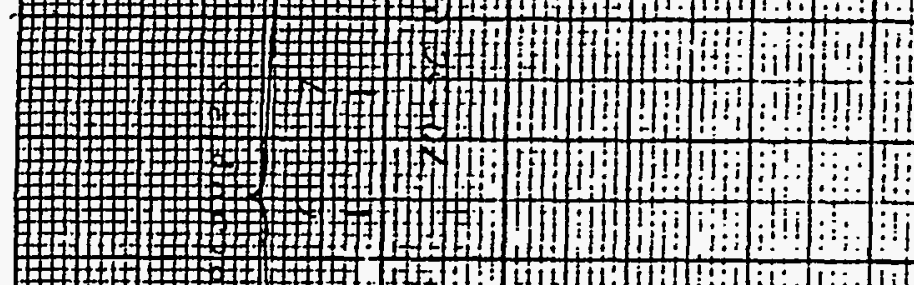

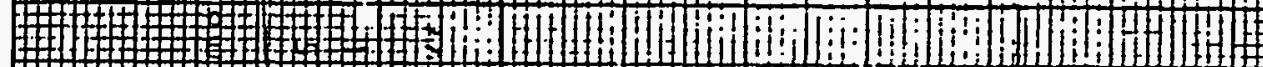

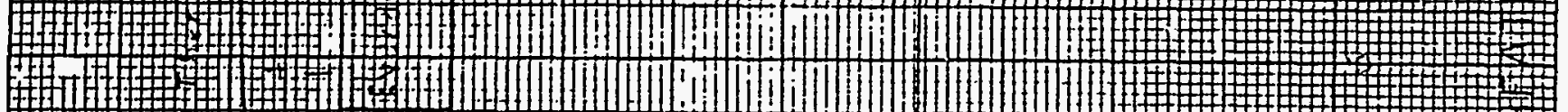

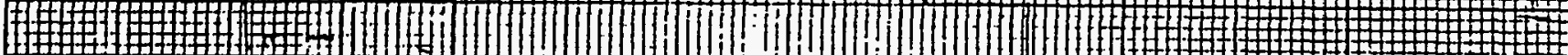
I

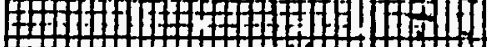

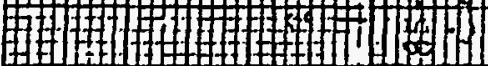

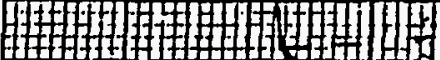

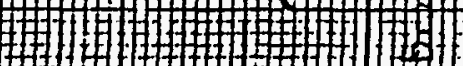

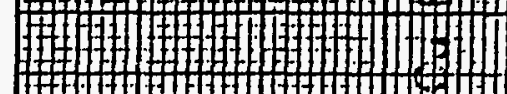

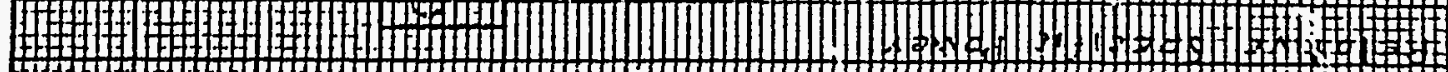
If

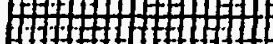

H.1.

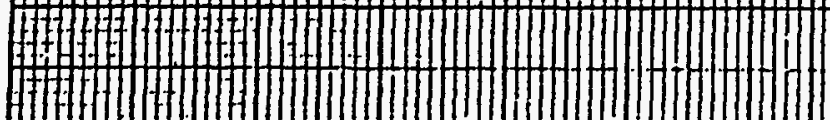

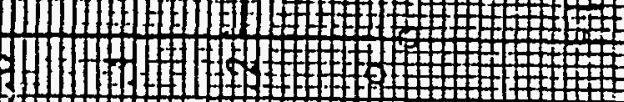
S3 平 $+7$

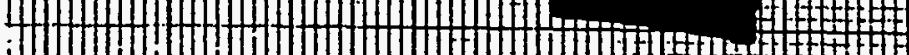
抹 (t) 